Original Research Paper

\title{
Economics of Boro Rice Production in Rangpur District of Bangladesh: Comparative Assessment of Urea Super Granule and Traditional Urea Application
}

\author{
${ }^{1}$ Md. Farhad Masum, ${ }^{1}$ Md. Monirul Islam, ${ }^{2}$ Arifa Jannat and ${ }^{1}$ Aurup Ratan Dhar \\ ${ }^{1}$ Department of Agricultural Economics, Bangladesh Agricultural University, Mymensingh-2202, Bangladesh \\ ${ }^{2}$ Institute of Agribusiness and Development Studies, Bangladesh Agricultural University, Mymensingh-2202, Bangladesh
}

\author{
Article history \\ Received: 08-01-2018 \\ Revised: 09-01-2018 \\ Accepted: 14-04-2018 \\ Corresponding Author: \\ Aurup Ratan Dhar \\ Department of Agricultural \\ Economics, Bangladesh \\ Agricultural University, \\ Mymensingh-2202, Bangladesh \\ Email: aurup971@gmail.com
}

\begin{abstract}
The study was examined the profitability of Boro rice production using Urea Super Granule (USG) and traditional urea in Rangpur district of Bangladesh. 60 farmers were selected randomly for the present study. The cultivation of Boro rice was profitable from the viewpoint of the farmers. Per hectare net return for USG user and traditional urea user was Tk. 40264.4 and Tk. 26740.2, respectively. Benefit cost ratio for USG user and traditional urea user was estimated at 1.5 and 1.3 , respectively. BCR was higher for USG user because they were efficient producer. Power tiller cost, seed/seedling cost, TSP cost, MoP cost, cowdung cost and irrigation cost; and human labor cost, seed/seedling cost, urea cost, MoP cost, cowdung cost and irrigation cost had significant impact on gross return from Boro rice production for USG and traditional urea user, respectively. Age of farmer, price of USG, soil nutrient availability and extension contact had significant impact on farmers' preference for using USG in Boro rice production. The price of fertilizer should be regulated strictly by the government and extension programs should be arranged in order to motivate farmers for adopting USG use in Boro rice production.
\end{abstract}

Keywords: Boro Rice, Urea Super Granule, Traditional Urea

\section{Introduction}

Bangladesh is an agro based and developing country and the country faced problems of low productivity, a chronic shortage of food supply, poverty, external dependence and high unemployment problem (Dhar and Uddin, 2017). Rice plays significant role in terms of food habit. It is also a primary staple food for large proportion of people in the developing countries. Before liberation in this country food deficit was common phenomenon. After liberation different research organizations developed HYV of rice. As a result, food deficit has been gradually decreased. To increase this production the research organizations and the Department of Agricultural Extension (DAE) are playing the most important role. About $75 \%$ of the total cropped area and over $80 \%$ of the total irrigated area is planted to rice (BBS, 2014). Thus, rice plays a vital role in the livelihood of the people of Bangladesh. However, there is no reason to be complacent. The population of Bangladesh is still growing by two million every year and may increase by another 30 million over the next 20 years. Thus, Bangladesh will require about 27.26 million tons of rice for the year 2020. During this time total rice area will also shrink to 10.28 million hectares. Rice yield therefore, needs to be increased from the present 2.74 to $3.74 \mathrm{t} / \mathrm{ha}$ (BER, 2013).

Balanced fertilization is the key to enhance the rice production. Nitrogenous fertilizer is playing pivotal role in this aspect. Modern rice varieties like, the HYVs need more fertilizers. It is widely recognized that nitrogen fertilizer use in Bangladesh needs special emphasis. Nitrogen deficit is found in almost all types of soils of Bangladesh for the low level organic matter content. Unfortunately the efficiency of nitrogen fertilizers in wet land rice cultivation is very low and it is only $30 \%$ of the applied nitrogen (Prasad and De Datta, 1979). Urea is the major nitrogenous fertilizer used in Bangladesh for rice cultivation. At present the farmers pay Tk.1000 per hectare for urea during rice cultivation and the farmers vastly use it. But about $60-70$ percent of urea is lost due to broadcasting in prilled form (Hasan, 2000). This loss occurs in the form of ammonia volatilization, denitrification, run-off and leaching. This loss increases the 
production cost and also pollutes the environments as well. To reduce this considerable loss, Urea Super Granule (USG) has been introduced which is locally known as "Guti urea". This is recommended for the deep placement in the rice field.

This urea is an innovation, which enhances the efficiency of urea and also reduces the cost of fertilizer in rice field. In Bangladesh research of USG started in early eighties. The efficiency of USG compared to prilled urea in increasing the yield of Boro rice by roughly 20 percent was demonstrated in a number of studies conducted by different organizations in the country (Paul, 2000). Similarly it also exhibited the increase in yield of transplanted Aman rice in a case study in Tangail district (Hoque, 1998). Soil science division of BRRI (Bangladesh Rice Research Institute) conducted several researches on USG in wet land rice. The relative advantage of USG compared with Prilled Urea (PU) has been revealed in those researches.

Whenever an innovation is generated then efforts have been made to adopt the innovation (Dhar et al., 2018). To meet up the increasing need of this country and to increase the agricultural production new technologies are always encouraged and emphasis given to adopt them by the farmers. To gear up the production of rice farmers are being encouraged to adopt balanced fertilization. USG is an innovation related to the production of rice and it has already been proved that this nitrogenous fertilizer is effective in nutrient uptake and increase production and also reduces the production cost of rice. As USG is an innovation it should have the attributes of: (a) relative advantage; (b) compatibility; (c) complexity; (d) trainability; and (e) observability (Rogers, 1983). The farmers also adopted this innovation with the passes of time. Considering the above facts and findings the researcher has become eager to undertake the present study, the purpose of which is to determine the categories of USG adopters.

Agriculture is the mother board of Bangladesh economy like a computer. None can think about economic progress without modernization of agriculture. It plays a vital role in the initial stage of development. The economy of Bangladesh mostly depends on rice production. Rice is the staple food for entire 149.7 million people of Bangladesh. So, without modernizing agriculture, it is not possible to produce sufficient food grain to meet food demand for its increased population. Keeping this in mind, since independence all the successive governments have given high priority for attaining self-sufficiency in food grain production. The development of high-yield grain Boro rice which is highly responsive to inorganic fertilizer and insecticides, effective soil management and water control helped the country to meet the increasing requirement of food grain. In recent years however, the share of Boro is increasing. Boro rice production depends on fertilizer uses. Most of the farmers used different kinds of fertilizers because of higher production. In this case, urea application plays significant role for Boro rice production.

Many researchers have reported that USG had better effect on grain yield and yield contributing characteristics than PU. Thus, there may have enough scope of investigating the effect of forms of nitrogen fertilizer for favors the yield improvement of Boro rice. The studies conducted so far focused on the cost, return, yield and some economic aspects of Boro rice production. Comparative studies on USG and traditional urea in Boro rice are much limited in number in the country. So, the present research has been undertaken to make an in-depth study to fill in the knowledge gap in the field of Boro rice production especially for the varieties of 'BRRI dhan 28' and 'BRRI dhan 29'. It is expected that the present study would provide valuable information to the farmers and would also indicate the adjustment needed in the allocation of the farm resources. The farmers will get information regarding the urea cost. An individual will be able to see the performances and will gain an insight into the question of how much improve his farming because of urea or fertilizers used. The study will identify the factors motivating farmers' preference for using USG in Boro rice production. The study will also furnish some basic information to the policy maker about the suitability of USG and traditional urea for Boro rice production in the context of Bangladesh. In addition to this the study will aid policy makers in making decisions involving for using fertilizers in case of Boro rice production.

The overall goal of the study is to examine the comparative profitability of USG and traditional use in Boro rice production; and point out the determinants influencing farmers' preference to use USG in Boro rice production in some selected areas of Rangpur district in Bangladesh. The specific objectives of the study are as follows:

i. To estimate and compare the cost and return of Boro rice production using USG and traditional urea

ii. To determine factors influencing gross return of Boro rice production using Guti urea

iii. To identify the factors motivating farmers' preference for using USG in Boro rice production

\section{Materials and Methods}

\section{Selection of the Study Area}

Considering the objectives of the study, Taragonj, Pirgonj and Mithapukur upazilas in Rangpur district were selected as the study areas. Villages namely Kaligangpara, Mushapur, Kisamat Melanagar, Nayankhal, Milky and Garagram were covered for collecting necessary information for the study. 


\section{Sample Size and Sampling Technique}

A total of 60 farmers (i.e., 30 farmers from USG user and 30 farmers from traditional urea user) were selected through purposive random sampling technique. Figures 1 and 2 depict the types of urea used in this study. Boro season generally begins in January to February and ends in mid-April to May. Necessary primary data of USG user and traditional urea user were collected by the researchers through questionnaire interview with a structured questionnaire. Secondary data and information from different reports, publications, notifications, etc. relevant to this study were also collected and analyzed for this study.

\section{Analytical Techniques}

The collected data was analyzed on the basis of the objectives of the study by using descriptive statistics, mathematical and statistical analysis. Descriptive statistics were used to represent the socioeconomic characteristics of the respondents.

\section{Mathematical Analysis}

Mathematical analysis included the profitability of Boro rice by using USG and traditional urea. Profitability was calculated in terms of gross return, gross margin, net return and benefit cost ratio (BCR).

\section{Gross Return}

Gross return was calculated by simply multiplying the total volume of output of rice with per unit price received by the farmers. It was consisted sum of the volume of main product and it's by product (Dillon and Hardaker, 1993):

$$
\text { Gross } \operatorname{Return}=\sum(Q \times P)
$$

Where,

$Q=$ Quantity of the product

$P=$ Average price of the product

\section{Gross Margin}

Gross margin is the gross return over variable cost:

$$
\text { Gross Return = Gross return }- \text { Total var iable cost }
$$

\section{Net Return}

Net return was obtained by deducting all costs (variable and fixed) from gross return.

$$
\text { Net return, } \pi=\sum\left(P_{y} \times Y\right)-\sum\left(P_{x} \times X\right)-T F C
$$

Where,

$$
\begin{array}{ll}
P_{y} & =\text { Price per unit of produce } \\
Y & =\text { Quantity of the produce } \\
P_{x} & =\text { Price per unit of inputs } \\
T F C & =\text { Total fixed costs }
\end{array}
$$

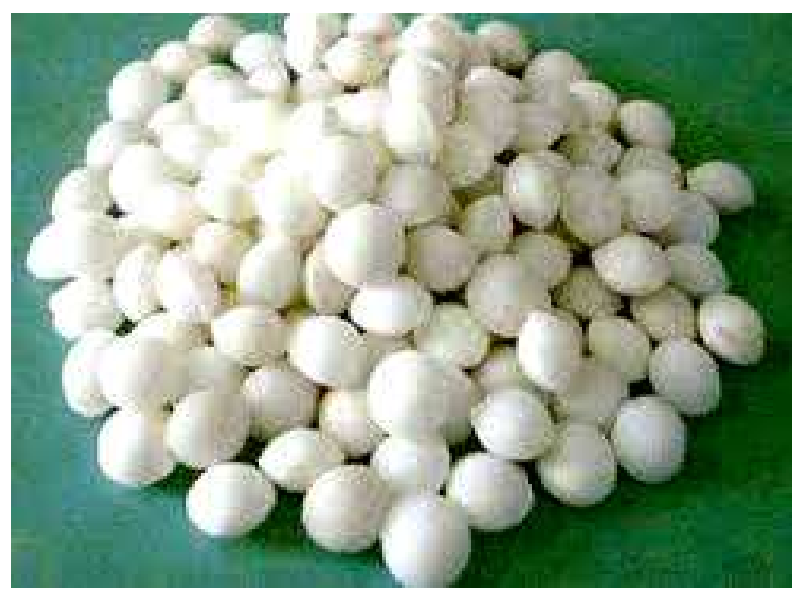

Fig. 1: Urea Super Granule (USG)

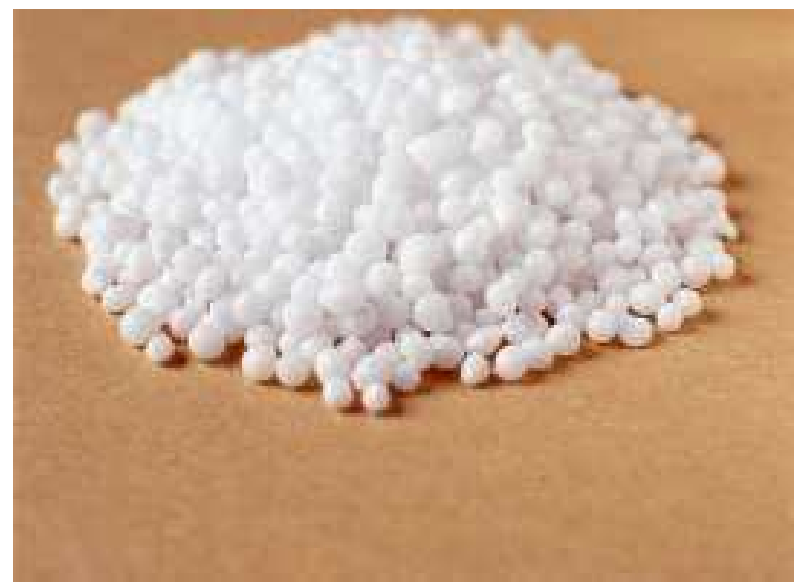

Fig. 2: Traditional urea

\section{Benefit Cost Ratio (BCR)}

The $\mathrm{BCR}$ is a relative measure, which is used to compare benefit per unit of cost. The BCR estimated as a ratio of gross returns and gross costs. The formula of calculating BCR (undiscounted) is shown below:

$$
\text { Benefit cost ratio }=\text { Gross benefit } \div \text { Gross cost }
$$

\section{Statistical Analysis}

\section{Cobb-Douglas Production Function}

In order to estimate the effects of key variables in the Boro rice production, the Cobb-Douglas form of production function was used. The specification of the Cobb-Douglas production function for Boro rice production with USG and traditional urea was as follows (Nerlove, 1965):

$$
Y_{i}=a X_{1}^{b_{1}} X_{2}^{b_{2}} X_{3}^{b_{3}} X_{4}^{b_{4}} X_{5}^{b_{5}} X_{6}^{b_{6}} X_{7}^{b_{7}} X_{8}^{b_{8}} X_{9}^{b_{9}} e^{u_{i}}
$$


The Cobb-Douglas production function was transformed into following logarithmic form so that it could be estimated by the Ordinary Least Squares (OLS) method:

$$
\begin{aligned}
\ln Y_{i}= & \ln a+b_{1} \ln X_{1}+b_{2} \ln X_{2}+b_{3} \ln X_{3}+b_{4} \ln X_{4} \\
& +b_{5} \ln X_{5}+b_{6} \ln X_{6}+b_{7} \ln X_{7}+b_{8} \ln X_{8} \\
& +b_{9} \ln X_{9}+u_{i}
\end{aligned}
$$

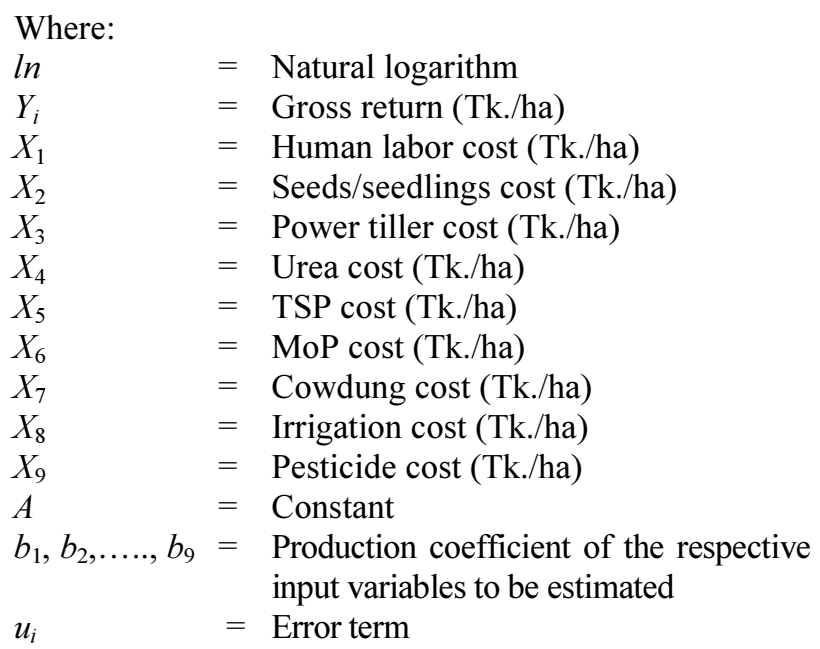

\section{Multinomial Logit Model}

In order to investigate the extent of influence of the determinants on farmers' preference for using USG in Boro rice production, multinomial logit model was used. In the present study, the following variables were used to estimate the model (Bruin, 2006):

\section{Dependent Variable}

Extent of preferring USG use in Boro rice production by the farmers ( 1 indicates enhanced, 2 indicates declined and 3 indicates neutral preference).

\section{Independent Variables}

Educational level of farmer (years of schooling); Age of farmer (years); Farming experience (years of farming); Price of USG (Tk.); Soil nutrient availability (1 indicates sufficient nutrient availability and 0 indicates otherwise); and Extension contact ( 1 indicates having extension contact and 0 indicates otherwise).

\section{Results and Discussion}

\section{Socioeconomic Characteristics of the Sample Farmers}

This part provides information on age distribution, educational status, male-female ratio and occupational status of the respondents in the research areas. In the study, family size (members) has been defined as total number of persons living together and taking meals from the same kitchen under the administration of the same head of the family. About 43.3 percent farmers were between 31-40 years and 30 percent farmers belonged to above 51 years of age category. The percentage of illiterate farmers in the case of traditional urea user was higher where there was no illiterate farmer in USG user. Total family members of traditional urea user farm families were 136, of whom 53 are male and 68 are female. In case of USG user farm families, the total family members were 147, of whom 73 are male and 72 are female. Agriculture is the main occupation and source of livelihood of the selected heads of the households in the study area. Besides agriculture, some farmers were engaged in petty trading and others are employed in government, semi government or private services. In case of traditional urea user, 70 percent farmers were engaged in cultivation as main profession and 30 percent as subsidiary, 13.3 percent in business and 13.3 percent in service. In case of USG user, 93.3 percent farmers were engaged in agriculture mainly and 6.7 percent as secondarily. The percentage of cultivation in case of traditional urea user is less than that of USG user and they were fewer involved with business rather than traditional urea users.

\section{Comparative Profitability of Boro Rice using USG and Traditional Urea}

The objective of this section is to assess the profitability of Boro rice production with USG and traditional urea. Full cost and cash cost have been considered in calculating gross cost. Cash cost includes all cash expenses while full cost includes all cash and non-cash expenses including land use cost and interest on operating capital.

\section{Estimation of Variable Cost}

Variable costs are the costs of using the variable inputs. These costs vary with the level of production. There are some necessary inputs like seed, human labor, fertilizer, irrigation etc. These costs considered as variable costs of Boro rice is discussed under the following headings.

\section{Human Labor Cost}

Human labor is the most important and largely used input for producing Boro rice. It required for different operations i.e., land preparation, sowing transplanting, weeding, application of fertilizer and insecticide, harvesting and carrying, threshing, cleaning, drying etc. and was computed in terms of man-days. Table 1 reveals that in producing Boro rice with USG, per hectare total labor cost was estimated at Tk. 32435.6 and for traditional user it was Tk. 31412.5. 
Table 1: Cost of Boro rice production

\begin{tabular}{|c|c|c|c|}
\hline \multirow{2}{*}{\multicolumn{2}{|c|}{$\frac{\text { Items }}{\text { A. Variable cost }}$}} & By USG & By traditional urea \\
\hline & & & \\
\hline \multicolumn{2}{|l|}{ Human labor } & 32435.6 & 31412.5 \\
\hline \multicolumn{2}{|l|}{ Power tiller } & 8940.4 & 7274.3 \\
\hline \multicolumn{2}{|l|}{ Irrigation } & 8610.1 & 9261.3 \\
\hline \multicolumn{2}{|l|}{ Seed } & 3572.4 & 3035.2 \\
\hline \multirow[t]{9}{*}{ Fertilizers } & USG/Traditional urea & 2332.7 & 4696.8 \\
\hline & TSP & 2063.1 & 4254.7 \\
\hline & MP & 1239.2 & 2638.3 \\
\hline & Gypsum & 81.4 & 270.9 \\
\hline & $\mathrm{ZnSO}_{4}$ & 1055.0 & 838.6 \\
\hline & Boron & 80.9 & 0.0 \\
\hline & Vermicompost & 2063.1 & 221.8 \\
\hline & Cowdung & 7771.9 & 8759.1 \\
\hline & Total fertilizer cost & 16687.3 & 21680.2 \\
\hline \multicolumn{2}{|l|}{ Interest on operating cost } & 2661.4 & 2694.4 \\
\hline \multicolumn{2}{|l|}{ Total variable cost } & 73594.9 & 76963.4 \\
\hline \multicolumn{4}{|l|}{ B. Fixed cost } \\
\hline \multicolumn{2}{|l|}{ Land rental cost } & 5763.3 & 4610.7 \\
\hline \multicolumn{2}{|l|}{ Interest on operating capital } & 2661.4 & 2694.4 \\
\hline \multicolumn{2}{|l|}{ Total fixed cost } & 8424.7 & 7305.1 \\
\hline \multicolumn{2}{|l|}{ C. Gross cost $(A+B)$} & 82019.6 & 84268.5 \\
\hline
\end{tabular}

Source: Authors' estimation, 2015

\section{Power Tiller Cost}

In the study area farm mechanization made tremendous progress as hundred percent farmers used power tiller for tillage operation. Per hectare power tiller cost for land operation of both USG and traditional urea user farmer was estimated at Tk. 8940.4 and Tk. 7274.3, respectively (Table 1).

\section{Cost of Irrigation}

In the study area the entire farmer uses irrigation for their cultivation. Per hectare irrigation cost for land operation of both USG and traditional urea user farmer was estimated at Tk. 8610.1 and Tk. 9261.3 respectively (Table 1).

\section{Cost of Seed/Seedling}

Seed is the basic input for crop production. The costs of seed for Boro rice production by USG user and traditional urea user were Tk. 3572.4 and 3035.2 per hectare which were 8.7 and 6.7 percent of total material costs respectively.

\section{Cost of Fertilizers}

In the study area, USG user rice producers used the following types of fertilizers available such as USG, TSP, MP, Gypsum, Zinc sulphate, Boron, vermicompost and cowdung. USG user rice producers used $136.9 \mathrm{~kg} / \mathrm{ha}$ USG, $93.8 \mathrm{~kg} / \mathrm{ha}$ TSP, $82.6 \mathrm{~kg} / \mathrm{ha} \mathrm{MP,} 16.3 \mathrm{~kg} / \mathrm{ha}$ Gypsum, $12.3 \mathrm{~kg} / \mathrm{ha}$ Zinc sulphate, $0.7 \mathrm{~kg} / \mathrm{ha}$ Boron, $408.4 \mathrm{~kg} / \mathrm{ha}$ vermicompost and $7771.9 \mathrm{~kg} / \mathrm{ha}$ cowdung. On the other hand, traditional urea user rice producers used $276.3 \mathrm{~kg} / \mathrm{ha}$ urea, $276.3 \mathrm{~kg} / \mathrm{ha}$ TSP, $175.9 \mathrm{~kg} / \mathrm{ha}$ MP, $54.2 \mathrm{~kg} / \mathrm{ha}$
Gypsum, $7.1 \mathrm{~kg} / \mathrm{ha}$ Zinc sulphate, $100.8 \mathrm{~kg} / \mathrm{ha}$ vermicompost and $7324.2 \mathrm{~kg} / \mathrm{ha}$ cowdung. Total fertilizer cost of USG and traditional urea user rice producers was Tk. 16687.3 and Tk. 21680.2, respectively (Table 1).

\section{Cost of Insecticides}

Both the Guti urea user and traditional urea user rice producers used insecticide to protect their crops from pest attack. They used insecticides like Furadon, Dimecron, Bashudin, Falliqul, etc. In the study area per hectare insecticide costs were Tk.3349.2 and Tk.4299.9 for Guti and traditional urea user, respectively.

\section{Estimation of Fixed Cost}

Fixed costs are costs which do not change in magnitude as the amount of output changes and are incurred even when production is not undertaken. The interest on operating capital and land use cost were considered as fixed cost rice production in this study.

\section{Land Use Cost}

In the study area, most of the farmers had own land for producing Boro rice. The seasonal rental cost of land was treated as land use cost for the farmers. Land use cost was a fixed cost for the producers. Per hectare land use cost for Mithapukur region is Tk. 24500 and Taragonj, Pirgang region is Tk. 19600 in Rangpur district for six month.

\section{Interest on Operating Cost}

Interest on operating cost includes variable costs in the production of Boro rice by USG user for a period of 
6 months and traditional urea user for a period of 6 months production period. Interest rate of 14 percent per annum for both varieties was considered for calculation. The interest actually means the average operating costs over the time period as all the costs were not incurred at the same time; rather these were used throughout the production period from beginning to the end. Interest on operating cost for USG user and traditional urea user for Boro rice production was Tk. 2575.8 and Tk. 2693.72 per hectare, respectively.

\section{Gross Cost}

Gross cost was calculated by adding all costs of variable inputs and fixed inputs. On the basis of gross cost per hectare, production costs of Boro rice for USG and traditional urea user were estimated at Tk. 82019.7 and Tk. 84268.5, respectively. Per hectare gross cost of USG using was lower than that of traditional urea using in Boro rice in the study area (Table 1).

\section{Estimation of Return}

\section{Gross Return}

Per hectare gross returns were calculated by multiplying the total amount of product and by-product with their respective farm gate prices. Per hectare yield of Boro rice using USG and traditional urea were 6599.5 $\mathrm{kg}$ and $6905.6 \mathrm{~kg}$, respectively. Table 2 shows that per hectare gross returns of traditional urea user were lower than that of USG user. In terms of monetary unit, the value of Boro rice produced per hectare was Tk. 115273.9 for USG user and Tk. 107978.5 for traditional urea user. Taking the by-product value into account, per hectare total gross returns were Tk. 122284.07 and Tk. 111008.7 for USG and traditional urea user, respectively. Thus, it was clear that USG user farmer earned relatively higher gross return than that of traditional urea user farmer in Boro rice per hectare.

\section{Gross Margin}

It is known that gross margin is the difference between total variable cost and total return. Per hectare gross margin of the enterprises was obtained by deducting total variable cost from total return. Per hectare gross margin of USG user and traditional user in Boro rice production were estimated at Tk. 48689.2 and Tk. 34045.3, respectively (Table 3).

\section{Net Return}

Net return was calculated by deducting total cost from total return. Net return from Boro rice by using USG and traditional urea was Tk. 40264.4 and Tk. 26740.2, respectively. Net returns for USG user were higher than traditional urea user, because cost of production for using USG is less and per hectare yield is high than the traditional urea user. So, per hectare profitability of USG user was higher than that of traditional urea user (Table 3).

\section{Benefit Cost Ratio (BCR)}

It is a measure to see the efficiency of resource use. Table 3 shows that BCR (undiscounted) of Boro rice production for USG and traditional urea user was emerged as 1.5 and 1.3 , respectively implying that Tk. 1.5 and Tk. 1.3 would be earned by investing every Tk. 1.0 in Boro rice production by using USG and traditional urea, respectively. The results indicated that investment in Boro rice production using USG were relatively profitable than using traditional urea. Hussain et al. (2017) supported the findings where the authors found that the performance of USG in terms of growth, yield and yield attributes, head quality (compactness coefficient) and economic profitability was significantly higher as compared to that of PU.

Table 2: Return from Boro rice production

\begin{tabular}{|c|c|c|c|c|c|}
\hline \multirow[b]{2}{*}{ Boro rice production } & \multicolumn{3}{|l|}{ Main product } & \multirow{2}{*}{$\begin{array}{l}\text { Value of by-product } \\
\text { (Tk./ha) }\end{array}$} & \multirow{2}{*}{$\begin{array}{l}\text { Gross return } \\
\text { (Tk./ha) }\end{array}$} \\
\hline & Quantity (Kg/ha) & Price $(\mathrm{Tk} . / \mathrm{kg})$ & Value (Tk./ha) & & \\
\hline By USG & 6599.5 & 17.5 & 115274.0 & 7010.1 & 122284.1 \\
\hline By traditional urea & 6905.6 & 15.6 & 107978.5 & 3030.2 & 111008.7 \\
\hline
\end{tabular}

Source: Authors' estimation, 2015

Table 3: Profitability of producing boro rice

\begin{tabular}{lrr}
\hline Items & By USG & By traditional urea \\
\hline Gross return (Tk./ha) & 122284.1 & 111008.7 \\
Total variable cost (Tk./ha) & 73594.9 & 76963.4 \\
Total fixed cost(Tk./ha) & 8424.7 & 7305.1 \\
Gross cost (Tk./ha) & 82019.6 & 84268.5 \\
Gross margin (Tk./ha) & 48689.2 & 34045.3 \\
Net return (Tk./ha) & 40264.4 & 26740.2 \\
BCR (Undiscounted) & 1.5 & 1.3 \\
\hline
\end{tabular}

Source: Authors' estimation, 2015 


\section{Factors Influencing Gross Return from Boro Rice Production}

This part has been made to identify and measure the effects of the factors of production on gross return of Boro rice production in the framework of production function analysis. For the purpose Cobb-Douglas production function model has been chosen to estimate the effects of selected inputs on Boro rice production. Efforts have been made in this section to make a functional analysis of Boro rice production using USG and traditional urea, which can provide a compromise between (i) adequate fit of the data (ii) computational feasibility and (iii) sufficient degrees of freedom unused to allow for statistical testing with the help of samples.

\section{Empirical Results of Cobb-Douglas Production Function}

Estimated values of co-efficient and related statistics of Cobb-Douglas production function model for Boro rice production for USG and traditional urea user are shown Table 4 . Twelve explanatory variables were taken into consideration for production function analysis of the farmers' efficiency in Boro rice production.

\section{Functional Relationship}

The estimated production function for USG user was:

$$
\begin{aligned}
\ln Y_{1}= & 5.299-0.100 \ln X_{1}+1.804 \ln X_{2}-0.845 \ln X_{3} \\
& -0.167 \ln X_{4}-0.291 \ln X_{5}+0.318 \ln X_{6} \\
& -0.020 \ln X_{7}+0.153 \ln X_{8}-0.006 \ln X_{9}
\end{aligned}
$$

Again, the estimated production function for traditional urea user was:

$$
\begin{aligned}
\ln Y_{2}= & 5.666-0.752 \ln X_{1}+0.079 \ln X_{2}-2.252 \ln X_{3} \\
& -0.288 \ln X_{4}-0.0 .163 \ln X_{5}+0.501 \ln X_{6}+ \\
& 0.028 \ln X_{7}+0.438 \ln X_{8}+0.016 \ln X_{9}
\end{aligned}
$$

\section{Explanation of Explanatory Variables}

\section{Human Labor Cost}

It can be seen from Table 4 that regression coefficient of human labor cost were -0.100 and -0.752 for USG and traditional urea user and both are negative, respectively. It was insignificant for USG user and significant for traditional urea user. It indicates that 1 percent increase in human labor cost for USG and traditional urea user, remaining other factors constant, would decrease in gross return by 0.100 and 0.752 percent, respectively.

\section{Power Tiller Cost}

It can be seen from Table 4 that regression coefficients of power tiller cost were 1.804 and -0.079 for USG and traditional urea user, respectively. For USG user, it was significant at 1 percent level which indicates that 1 percent increase in power tiller cost for USG user, remaining other factors constant, would result increase in gross return by 1.804 percent. On the other hand, for traditional urea user, it was insignificant which indicates that an increase in 1 percent power tiller cost, remaining other factors constant, would result decrease in the gross return by 0.079 percent.

\section{Seed/Seedling Cost}

The regression coefficients of seed/seedling cost were -0.845 and 2.252 for USG and traditional urea user, respectively. For USG user it was negative and significant at 5 percent level which indicates that 1 percent increase in seed/seedling cost, remaining other factors constant, would result decrease in gross return by 0.845 percent. And for traditional urea user, it was positive and insignificant which indicates that an increase in 1 percent seed/seedling cost, remaining other factors constant, would result in an increase in the gross return by 2.252 percent (Table 4 ).

\section{Urea Cost}

The regression coefficients of USG and traditional urea cost were 0.318 and 0.501 for USG and traditional urea user, respectively. For USG user, it was positive and significant at 10 percent level which indicates that 1 percent increase in urea cost, remaining other factors constant, would result increase in gross return by 0.318 percent. And for traditional urea user, it was negative and significant at 1 percent level which indicates that an increase in 1 percent urea cost, remaining other factors constant, would result increase in the gross return by 0.501 percent.

\section{TSP Cost}

The coefficient of TSP cost was 0.291and 0.163and both were positive for USG and traditional urea user, respectively. For USG user, it was significant at 10 percent level which indicates 1 percent increase in TSP cost, other factors holding constant, would result increase in gross return by 0.291 percent. On the other hand for traditional urea, 1 percent increase in TSP cost, other factors holding constant, would result an increase in gross return by 0.163 percent.

\section{MoP Cost}

The coefficient of MoP cost was 0.167 and 0.288 for USG and traditional urea user and both were positive, respectively. For USG user, it was insignificant which indicating that 1 percent increase in Mop cost, keeping others factors constant, would increase in gross return of Boro rice production by 0.167 and for traditional urea user, it was significant at 10 percent level of significance which indicates that 1 percent increase in MoP cost, remaining other factors constant, would result increase in gross return by 0.288 percent (Table 4 ). 
Table 4: Estimated values of Cobb-Douglas production model

\begin{tabular}{|c|c|c|c|c|}
\hline \multirow[b]{2}{*}{ Explanatory variables } & \multicolumn{2}{|c|}{ Guti urea user } & \multicolumn{2}{|c|}{ Traditional urea user } \\
\hline & Coefficients & t-values & Coefficients & t-values \\
\hline Constant & $\begin{array}{l}5.299 \\
(0.922)\end{array}$ & 5.750 & $\begin{array}{l}5.666 \\
(1.152)\end{array}$ & 4.918 \\
\hline Human labor cost $\left(\mathrm{X}_{1}\right)$ & $\begin{array}{l}-0.100 \\
(0.099)\end{array}$ & -1.018 & $\begin{array}{l}-0.752 * * * \\
(0.381)\end{array}$ & -1.975 \\
\hline Power tiller $\operatorname{cost}\left(\mathrm{X}_{2}\right)$ & $\begin{array}{l}1.804^{*} \\
(0.383)\end{array}$ & 4.710 & $\begin{array}{l}-0.079 \\
(0.178)\end{array}$ & -0.441 \\
\hline Seed/Seedling cost $\left(\mathrm{X}_{3}\right)$ & $\begin{array}{l}-0.845^{* *} \\
(0.404)\end{array}$ & -2.094 & $\begin{array}{l}2.252^{*} \\
(0.780)\end{array}$ & 2.888 \\
\hline Urea cost $\left(\mathrm{X}_{4}\right)$ & $\begin{array}{l}0.318^{* * * *} \\
(0.161)\end{array}$ & 1.982 & $\begin{array}{l}0.501^{*} \\
(0.189)\end{array}$ & -2.647 \\
\hline $\mathrm{TSP} \operatorname{Cost}\left(\mathrm{X}_{5}\right)$ & $\begin{array}{l}0.291 * * * \\
(0.155)\end{array}$ & 1.885 & $\begin{array}{l}0.163 \\
(0.525)\end{array}$ & -0.310 \\
\hline $\mathrm{MoP} \operatorname{cost}\left(\mathrm{X}_{6}\right)$ & $\begin{array}{l}0.167 \\
(0.124)\end{array}$ & 1.342 & $\begin{array}{l}0.288 * * * \\
(0.156)\end{array}$ & -1.850 \\
\hline Cowdung cost $\left(\mathrm{X}_{7}\right)$ & $\begin{array}{l}0.020 * * * \\
(0.012)\end{array}$ & 1.713 & $\begin{array}{l}0.028^{* *} \\
(0.011)\end{array}$ & 2.477 \\
\hline Irrigation cost $\left(\mathrm{X}_{8}\right)$ & $\begin{array}{l}0.153 * * \\
(0.075)\end{array}$ & 2.051 & $\begin{array}{l}0.438^{* *} \\
(0.180)\end{array}$ & 2.431 \\
\hline Insecticide cost $\left(\mathrm{X}_{9}\right)$ & $\begin{array}{l}-0.006 \\
(0.111)\end{array}$ & -0.057 & $\begin{array}{l}0.016 \\
(0.013)\end{array}$ & 1.318 \\
\hline $\mathrm{R}^{2}$ & 0.65 & & 0.65 & \\
\hline F-value & 42.65 & & 39.35 & \\
\hline Return to scale & 0.89 & & 0.95 & \\
\hline
\end{tabular}

Source: Authors' estimation, 2015

Note: Figures in the parentheses indicate standard error

$*, * *$ and $* * *$ indicate significant at 1,5 and $10 \%$ percent probability level, respectively

\section{Cowdung Cost}

The regression coefficients of cowdung cost were 0.020 and 0.028 and both were positive for USG and traditional urea user, respectively. For USG user, it was significant at 10 percent level which indicates that 1 percent increase in cowdung cost, remaining other factors constant, would result increase in gross return by 0.020 percent. And for traditional urea user, it was significant at 5 percent level which indicates that an increase in 1 percent cowdung cost, remaining other factors constant, would result in an increase in the gross return by 0.028 percent.

\section{Irrigation Cost}

The regression coefficients of irrigation cost were 0.153 and 0.438 and both were positive for Guti urea and traditional urea user, respectively. For USG and traditional urea user, both were significant at 5 percent level indicating that 1 percent increase in irrigation cost, remaining other factors constant, would result increase in gross return by 0.153 and 0.438 percent, respectively.

\section{Insecticide Cost}

It can be seen that the regression coefficients of insecticide cost were -0.006 and 0.016 for USG and traditional urea user, respectively. For USG user, it was negative and insignificant which indicates that 1 percent increase in insecticide cost, remaining other factors constant, would result decrease in gross return by 0.006 percent. On the other hand, for traditional urea user, it was positive and insignificant which indicates that an increase in 1 percent insecticide cost, remaining other factors constant, would result increase in the gross return by 0.016 percent (Table 4$)$.

\section{Overall Performance of the Model}

\section{Value of $R^{2}$}

The coefficients of multiple determination $\left(\mathrm{R}^{2}\right)$ of the model were 0.65 for both of USG and traditional urea user, respectively. $\mathrm{R}^{2}$ of 0.65 for USG and traditional urea user indicated that about 65 percent variations in the gross return from Boro rice can be explained by the explanatory variables, which were included in the model (Table 4).

\section{Goodness of Fit (F-value)}

The F-values for USG and traditional urea were 42.65 and 39.35 which were significant at 1 percent level implying that all the explanatory variables were important for explaining the variations in gross returns of Boro rice production of USG and traditional urea user, respectively (Table 4). 


\section{Returns to Scale}

The summation of all the regression coefficients or production elasticity's of the estimated model gives information about the returns to scale, that is, in response of output to a proportionate change in all inputs. The sum of all the production coefficients of the equations for Boro rice production were 0.89 and 0.95 (Table 4) for USG and traditional urea user, respectively. These indicate that the production function exhibited decreasing returns to scale in Boro rice production for USG and traditional urea user, respectively.

Majumder et al. (2009) supported the findings slightly by stating that human labour cost, seedling cost, fertilizer cost and insecticide cost had significant influence on the gross return from HYV Boro rice in different tenural arrangements.

\section{Factors Motivating Farmers' Preference for Using USG in Boro Rice Production}

A multinomial logit model was used conveying the determinants influencing farmers' preference for using USG rather than traditional urea in Boro rice production. The target outcomes were farmers' enhanced and declined preference, whereas, the base outcome was farmer' neutral preference. Six explanatory variables were identified as major factors in this study (Table 5). The outcomes of the model are as follows:

\section{Preference Category: Enhanced Related to Neutral Educational Level of Farmer}

Table 6 indicates that the coefficient of educational level of farmer was 0.046 . The estimated value means that if farmers' preference for using USG in Boro rice production is to be increased by 1 point, the multinomial log-odds of farmers' educational level for enhanced preference relative to neutral preference is expected to be increased by 0.046 unit while holding all other variables in the model constant.

\section{Age of Farmer}

The coefficient of educational level of farmer was 0.098 and it was significant at $1 \%$ probability level. The estimated value means that if farmers' preference for using USG in Boro rice production is to be increased by 1 point, the multinomial log-odds of farmers' age for enhanced preference relative to neutral preference is expected to be increased by 0.098 unit while holding all other variables in the model constant (Table 5).

\section{Farming Experience}

Table 5 indicates that the coefficient of farming experience was 0.051 . The estimated value means that if farmers' preference for using USG in Boro rice production is to be increased by 1 point, the multinomial log-odds of farming experience for enhanced preference relative to neutral preference is expected to be increased by 0.051 unit while holding all other variables in the model constant.

\section{Price of USG}

The coefficient of price of USG was -0.061 and it was significant at $10 \%$ probability level. The estimated value means that if farmers' preference for using USG in Boro rice production is to be increased by 1 point, the multinomial log-odds of price of USG for enhanced preference relative to neutral preference is expected to be decreased by 0.098 unit while holding all other variables in the model constant (Table 5).

\section{Soil Nutrient Availability}

Table 5 represents that the coefficient of soil nutritional availability was 0.043 . The estimated value means that farmers' preference for using USG in Boro rice production is 0.043 unit higher in case of sufficient availability of soil nutrient compared to other condition while holding all other variables in the model constant.

\section{Extension Contact}

Table 5 depicts that the coefficient of extension contact was 0.001 . The estimated value means that farmers' preference for using USG in Boro rice production is 0.001 unit higher in case of having extension contact compared to other condition while holding all other variables in the model constant.

\section{Preference Category: Declined Related to Neutral}

\section{Educational Level of Farmer}

Table 5 indicates that the coefficient of educational level of farmer was 0.033 . The estimated value means that if farmers' preference for using USG in Boro rice production is to be increased by 1 point, the multinomial log-odds of farmers' educational level for enhanced preference relative to neutral preference is expected to be increased by 0.033 unit while holding all other variables in the model constant.

\section{Age of Farmer}

The coefficient of educational level of farmer was -0.006 . The estimated value means that if farmers' preference for using USG in Boro rice production is to be increased by 1 point, the multinomial log-odds of farmers' age for enhanced preference relative to neutral preference is expected to be decreased by 0.006 unit while holding all other variables in the model constant (Table 5). 
Table 5: Estimated values of multinomial logit model

\begin{tabular}{lllll}
\hline Farmers' preference & Factors & Coefficient & Standard error & $\mathrm{p}>|\mathrm{z}|$ \\
\hline Enhanced & Constant & -1.197 & 9.852 & 0.903 \\
& Educational level of farmer & 0.046 & 0.037 & 0.212 \\
& Age of farmer & $0.098^{* * *}$ & 0.037 & 0.002 \\
& Farming experience & 0.051 & 0.037 & 0.165 \\
& Price of USG & $-0.061^{*}$ & 0.035 & 0.067 \\
& Soil nutrient availability & 0.043 & 0.038 & 0.264 \\
Declined & Extension contact & 0.001 & 0.035 & 0.977 \\
& Constant & 23.755 & 9.602 & 0.013 \\
& Educational level of farmer & 0.033 & 0.269 \\
& Age of farmer & -0.006 & 0.030 & 0.853 \\
& Farming experience & 0.030 & 0.033 & 0.353 \\
& Price of USG & $-0.113 * * *$ & 0.038 & 0.007 \\
Neutral & Soil nutrient availability & $0.070^{*}$ & 0.035 & 0.046 \\
\hline
\end{tabular}

Source: Authors' estimation, 2015

Note: $* * *$ and $* * *$ indicate significant at $1 \%, 5 \%$ and $10 \%$ percent probability level, respectively

\section{Farming Experience}

Table 5 indicates that the coefficient of farming experience was 0.030 . The estimated value means that if farmers' preference for using USG in Boro rice production is to be increased by 1 point, the multinomial log-odds of farming experience for enhanced preference relative to neutral preference is expected to be increased by 0.030 unit while holding all other variables in the model constant.

\section{Price of USG}

The coefficient of price of USG was -0.113 and it was significant at $1 \%$ probability level. The estimated value means that if farmers' preference for using USG in Boro rice production is to be increased by 1 point, the multinomial log-odds of price of USG for enhanced preference relative to neutral preference is expected to be decreased by 0.113 unit while holding all other variables in the model constant (Table 5).

\section{Soil Nutrient Availability}

Table 5 represents that the coefficient of soil nutritional availability was 0.070 and it was significant at $10 \%$ probability level. The estimated value means that farmers' preference for using USG in Boro rice production is 0.070 unit higher in case of sufficient availability of soil nutrient compared to other condition while holding all other variables in the model constant.

\section{Extension Contact}

Table 5 depicts that the coefficient of extension contact was 0.061 and it was significant at $5 \%$ probability level. The estimated value means that farmers' preference for using USG in Boro rice production is 0.061 unit higher in case of having extension contact compared to other condition while holding all other variables in the model constant.

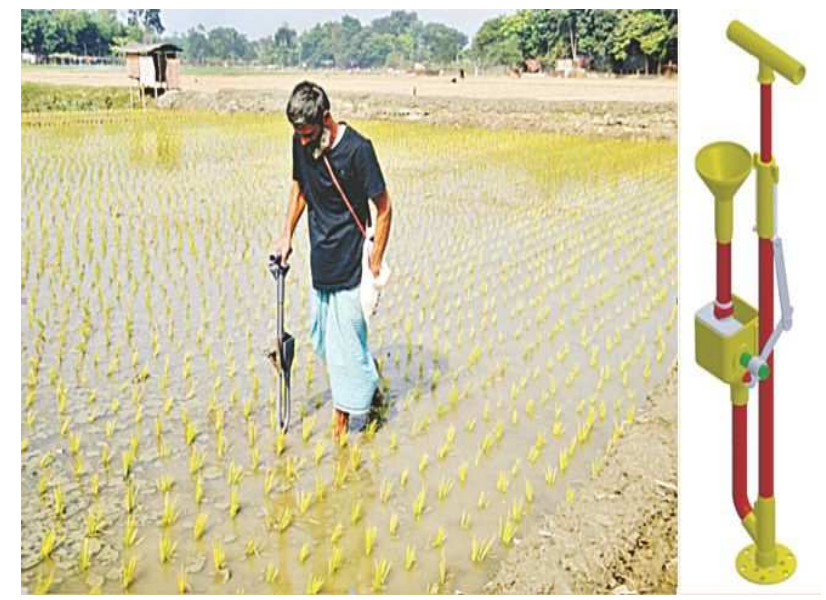

Fig. 3: Working with USG deep placement injector

The results are quite similar with Basak and Pandit (2011) where the authors showed that level of education, farm size, annual income, farming information, agricultural training exposure and rice farming knowledge of the farmers' had significant positive relationship but family subsistence pressure had significant negative relationship with their attitude towards the use of USG.

\section{A Case Study: Successful Story Of Using Usg}

The researchers spoke to local farmer Anwar Hossain Akash regarding the success of Guti urea (USG) in Pirgonj upazila (Fig. 3):

- "Do the farmers know about the benefits of Guti urea?"

- "Yes. They also know if they use it once, everything will work fine. Last season, I got very good result using Guti urea on Boro rice production

- "On one Pakhi of land (i.e., 30 decimal), how much urea do you use?" 
- "Previously we used to broadcast urea that took at least a maund. But injecting Guti urea through urea deep placement technology saved a lot of cost for me. Guti urea also yields more"

\section{Conclusion}

Production of Boro rice is more or less profitable in the study areas. USG users got higher profit compared to traditional urea users. Since, rice is the staple food for entire population of Bangladesh so, without modernizing agriculture, it is not possible to produce sufficient food grain to meet food demand for its increased population. The development of high-yield grain Boro rice which is highly responsive to inorganic fertilizer and insecticides, effective soil management and water control helped the country to meet the increasing requirement of food grain. Keeping the state of affairs in mind that, farmers' faces acute problem in Boro rice production. But most the farmers did not know about the application of input uses in right time with right doses. The study will help the farmers to solve their problems, needs and goals and can lead to viable production practices and sustainable income from Boro rice production. Some recommendations that arises from the findings are: government and non-government research institutions should strengthen their human resources for Boro rice production, seed costs should be decreased and the supply of seeds should be increased, the price of fertilizer and pesticides should be regulated strictly by the government and GOs and NGOs should run extension programs to motivate farmers for adopting USG use in Boro rice production.

\section{Acknowledgement}

The authors also express their earnest gratitude to the respondents and stakeholders of the study areas for their alliance and assistance in conducting surveys and collecting the data and information.

\section{Author's Contributions}

Md. Farhad Masum: Designed, collected and checked the analyzed data; prepared the draft manuscript and approved the final manuscript.

Md. Monirul Islam: Coordinated the study, analyzed the data and supervised the draft manuscript.

Arifa Jannat: Reviewed the draft manuscript and contributed in data interpretation.

Aurup Ratan Dhar: Coordinated the study, checked and analyzed the data, and prepared the draft manuscript.

\section{Ethics}

This article is original and contains unpublished material. The corresponding author confirms that all of the other authors have read and approved the manuscript and no ethical issues involved.

\section{References}

Basak, N.C. and J.C. Pandit, 2011. Farmers' attitude towards the use of usg in rice cultivation in three selected villages of netrakona district. J. Bangladesh Agric. Uni., 9: 179-185.

BBS, 2014. Yearbook of agricultural statistics of Bangladesh. Bangladesh Bureau of Statistics, Ministry of Planning, Government of the People's Republic of Bangladesh, Dhaka.

BER, 2013. Ministry of Finance, Government of the Peoples' Republic of Bangladesh.

Bruin, J., 2006. Newtest: Command to compute new test, UCLA: Statistical consulting group.

Dhar, A.R. and M.T. Uddin, 2017. Farmers' livelihood enhancement through conservation agriculture: A socioeconomic study. Lambert Academic Publishing, OmniScriptum AraPers GmbH, Haroldstraße, Düsseldorf, Germany.

Dhar, A.R., M.M. Islam, A. Jannat and J.U. Ahmed, 2018a. Adoption prospects and implication problems of practicing conservation agriculture in Bangladesh: A socioeconomic diagnosis. Soil Till. Res., 176: 77-84. DOI: 10.1016/j.still.2017.11.003

Dillon, J.L. and J.B. Hardaker, 1993. Farm management research for small farmer development, FAO, Rome, Italy.

Hasan, M.T., 2000. Impact of future plane of USG deep placement technology. Proceedings of the 2nd National Workshop on USG Deep Placement Technology and Sustainable Agriculture in Bangladesh Held at IDB Bhaban Auditorium, Jun. 21-21, Sher-e-Bangla Nagar, Dhaka.

Hoque, M.A., 1998. Relationship of farmer's characteristics with their adoption of HYV rice as transplanted aman and other related aspects in Bhabakhali union of Mymenshingh district. MSc. Thesis, Department of Agricultural Extension, Bangladesh Agricultural University, Mymenshingh.

Hussain, M.J., A.J.M.S. Karim, A.R.M. Solaiman, M.S. Islam and M. Rahman, 2017. Effect of urea super granule and prilled urea on yield and yield attributes of broccoli (Brassica oleracea var. italica L.). Agriculturists, 14: 95-112. DOI: 10.3329/agric.v14i2.31354

Majumder, M.K., L. Mozumdar and P.C. Roy, 2009. Productivity and resource use efficiency of boro rice production. J. Bangladesh Agric. Uni., 7: 247-252. 
Nerlove, M., 1965. Estimation and Identification of Cobb-Douglas Production Functions. 1st Edn., Rand McNally and Company, pp: 193.

Paul, S.K., 2000. Attitude of the farmers towards the use of urea super granule on rice cultivation in abhaynagar upazilla under Jessore district. MSc. Thesis, Department of Agricultural Extension, Bangladesh Agricultural University, Mymensingh.
Prasad, R. and S.K. De Datta, 1979. Increasing Nitrogen Fertilizer Efficiency in Wetland Rice.In: Eos Bonas, The Philippines: Nitrogen and Rice, Prasad, R. and S.K. De Datta (Eds.), IRRI, pp: 465-479.

Rogers, E.M., 1983. Diffusion of Innovations. 3rd Edn., The Free Press of Glencoe, New York,

ISBN-10: 0029266505, pp: 453. 